\title{
MICROBIOLOGICAL CONTAMINATION OF A HEMODIALYSIS CENTER WATER DISTRIBUTION SYSTEM
}

Lilian Bueno MONTANARI(1), Flávio Garcia SARTORI(1), Miguel Jorge de Oliveira CARDOSO(1), Samuel Dutra VARO(1), Regina Helena PIRES(1), Clarice Queico Fujimura LEITE(2), Karina PRINCE(2) \& Carlos Henrique Gomes MARTINS(1)

\begin{abstract}
SUMMARY
The microbiological monitoring of the water used for hemodialysis is extremely important, especially because of the debilitated immune system of patients suffering from chronic renal insufficiency. To investigate the occurrence and species diversity of bacteria in waters, water samples were collected monthly from a hemodialysis center in upstate São Paulo and tap water samples at the terminal sites of the distribution system was sampled repeatedly (22 times) at each of five points in the distribution system; a further 36 samples were taken from cannulae in 19 hemodialysis machines that were ready for the next patient, four samples from the reuse system and 13 from the water storage system. To identify bacteria, samples were filtered through $0.22 \mu \mathrm{m}$-pore membranes; for mycobacteria, 0.45 $\mu \mathrm{m}$ pores were used. Conventional microbiological and molecular methods were used in the analysis. Bacteria were isolated from the distribution system (128 isolates), kidney machine water (43) and reuse system (3). Among these isolates, 32 were Gram-positive rods, 120 Gram-negative rods, 20 Gram-positive cocci and 11 mycobacteria. We propose the continual monitoring of the water supplies in hemodialysis centers and the adoption of effective prophylactic measures that minimize the exposure of these immunodeficient patients to contaminated sources of water.
\end{abstract}

KEYWORDS: Dialysis; Water; Microbiological contamination; Water treatment; Dialysis fluid quality; Bacterial count.

\section{INTRODUCTION}

Patients with chronic renal insufficiency suffer from abnormalities of the immune system, as a direct result of uremia and its metabolic consequences, making them more susceptible to infections. Such abnormalities include impairment of the action of neutrophils, lymphocytes $\mathrm{B}$ and $\mathrm{T}$ and monocytes, leading to defective antigen processing, antibody production and cell-mediated immune response and thus to an increased incidence of microbial infections ${ }^{18,31}$.

Each patient using a kidney machine is exposed to between 18,000 and $36,000 \mathrm{~L}$ of water a year, from which, if it were not properly treated, a variety of chemical, bacterial and toxic contaminants could be transferred to the patients ${ }^{34}$.

The source of water used in hemodialysis consists basically of drinking water, purified by various techniques, whose composition and quality depend on its origin. In Brazilian hemodialysis units, a frequently used system of water treatment is reverse osmosis. Typically, water from the public supply passes through mechanical filters, water softeners, charcoal filters, deionizers and the reverse osmosis filter and is finally stored in tanks for subsequent distribution through polyvinyl chloride (PVC) tubing to the whole water system of the unit (Fig. 1). In such a system, the tubes, tanks and taps represent potential reservoirs for microorganisms that contribute to biofilms which, once formed, are extremely hard to eradicate by chemical or mechanical means $9,27,34$.

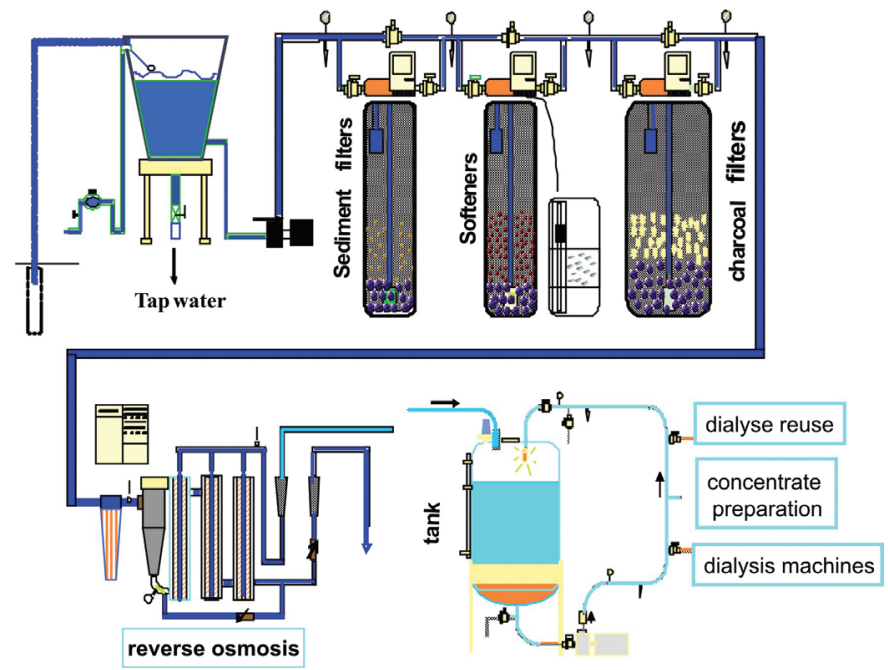

Fig. 1 - Diagram of treatment and distribution system in the hemodialysis center studied. 


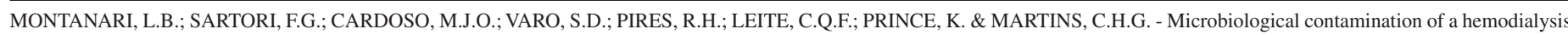
center water distribution system. Rev. Inst. Med. trop. S. Paulo, 51(1): 37-43, 2009.

Some studies reported the presence of biofilm in the tubing carrying hemodialysis fluids and noted its high resistance to biocides. This bacterial biofilm can lead to the recurring diffusion of toxins into the blood of patients undergoing hemodialysis, causing chronic inflammation. Various bacteria are described in the literature as capable of forming biofilm, e.g. Pseudomonas and Burkholderia species and mycobacteria ${ }^{9,32,35}$. Compared to many other bacterial species, mycobacteria are exceptionally resistant to chemical disinfectants, such as chlorine ${ }^{35}$. However, ARVANITIDOU et al. ${ }^{5}$ point to Gram-negative bacteria as the main contaminants of the water associated with the hemodialysis unit. These bacteria use the dialysing solution as a source of nutrients for growth $\mathrm{th}^{3,34}$.

Although the role of the quality of water used for hemodialysis has been emphasized by several authors ${ }^{6,7,15}$, few standards have been developed so far, as recommended by the Association for the Advancement of Medical Instrumentation (AAMI) ${ }^{2}$ and the European Best Practice Guidelines for Hemodialysis ${ }^{13}$. In some countries, investigations have revealed that the contamination levels in many samples of water treated for use in kidney machines and samples of dialysis solution are above the AAMI limit (200 CFU/mL heterotrophic bacteria) $)^{5,15}$. According quality criteria for dialysis water in the Brazilian Health Ministry (Res. RDC 154/GM, 15/6/2004), the number of microorganisms in these fluids should not exceed $200 \mathrm{CFU} / \mathrm{mL}$ and both the water and dialysate should be tested microbiologically at least once a month or immediately following a pyrogenic reaction or septicemia in a patient undergoing dialysis, as well as after any modification of the water treatment or distribution system.

Nevertheless, routine microbial checks performed at hemodialysis centers do not include analysis of mycobacteria or fungi, and there are few published reports of the isolation and identification of these $\operatorname{organisms}^{11,12,29,30}$.

The aim of this study was to investigate the microbiological quality of the dialysis water and sterilization solutions used at a hemodialysis center by isolating and identifying the Gram-negative and Gram-positive bacteria and mycobacteria.

\section{MATERIALS AND METHODS}

This study was conducted over a period of approximately two years (November, 2004 to July, 2006) in the hemodialysis center located in upstate São Paulo, having received the approval of the Research Ethics Committee of the University of Franca, SP, Brazil. Firstly, 110 samples of water were collected at the beginning of a dialysis treatment, consisting of a series of 22 samples at each of five points in the water system: (I) municipal water supply to the dialysis center, (II) downstream of reverse osmosis filter, (III), (IV) and (V) water distribution system in three dialysis rooms, designated rooms A, B and C. Each sample was collected after 3-5 min free flow ${ }^{1}$. Samples from (I) were treated with $1 \mathrm{~mL} 1.8 \%$ sodium thiosulfate per liter, to remove residual chlorine. In addition, 36 samples were taken from 19 kidney machines, before use or during patient changeover, after they were disinfected and ready for a new session; four samples of cleaning water from the dialyser reuse system and 13 from the water storage tank. Finally, 10 samples were taken from the sterilizing solutions in which dialysers had been kept after being washed for reuse with post-reverse osmosis treated water. One-liter water samples $(n=173)$ were collected in a sterilized flask and sent directly to the Laboratory of Research in Applied Microbiology at the University of Franca (UNIFRAN, SP, Brazil), to be analyzed within two hours of collection.

Bacteriological quantification and isolation: With a view to counting the number of bacteria suspended in each water sample, bacteria counts were done in duplicate on Reasoner's 2A agar (R2A -Difco) by the spread plate technique and plates were incubated at $25^{\circ} \mathrm{C}$ for five days, according to the American Public Health Association (APHA) ${ }^{1}$. At which time colonies were counted (total cell count) and the results are expressed as the mean of CFU (Colony Forming Units) per milliliter. Moreover, the number of CFU reflects the number of living cells that can grow under the conditions used i.e. medium, temperature and time. Total cell count includes both living and cells that can take up metabolized a certain stain ${ }^{22}$.

The membrane filtration is used as the concentrating technique, according to the water examination standard of American Public Health Association (APHA) ${ }^{1}$. Pore sizes of the membranes (Millipore, São Paulo, Brazil) were $0.45 \mu \mathrm{m}$ for mycobacteria and $0.22 \mu \mathrm{m}$ for other bacteria. For both Gram-negative and Gram-positive bacteria, following filtration, the $0.22 \mu \mathrm{m}$ membranes were placed in enrichment medium (peptone water) and incubated at $37{ }^{\circ} \mathrm{C}$ for $24 \mathrm{~h}$. Afterwards, samples showing cloudiness were seeded on plates of blood agar (Difco Labs, MD, USA), mannitol agar (Difco) and MacConkey agar (Difco) and incubated at 37 ${ }^{\circ} \mathrm{C}$ for $24 \mathrm{~h}$. In the assays for Mycobacterium, water sample was filtered and the membrane was treated with a solution of $4 \%$ sulfuric acid and neutralized with $30 \%$ solution of $\mathrm{NaOH}^{14,20}$, decontaminated and the retentate resuspended in $2.0 \mathrm{~mL}$ peptone water, from which two $0.2 \mathrm{~mL}$ aliquots were transferred to tube slants of Lowenstein-Jensen medium (Difco). One slant was incubated at ambient temperature and the other at $37^{\circ} \mathrm{C}$, for 60 days. Identification of Mycobacterium were performed by PRA (PCR and Restriction-enzyme pattern Analysis) ${ }^{36}$.

Identification: The pure bacterial isolates were subcultured on blood, mannitol or MacConkey agar and were identified by cultural and biochemical tests ${ }^{26}$. The commercial systems "BBL Crystal" Grampositive ID Kit and Enteric Nonfermenter ID Kit (Becton \& Dickinson, MD, USA) were required for the definitive identification of species isolated.

Colonies of mycobacteria were confirmed as acid-fast rods by the Ziehl-Neelsen staining method and then identified by PRA. The bacterial DNA was first extracted by applying a thermal shock consisting of three cycles of boiling $(10 \mathrm{~min})$ followed by freezing to $-20{ }^{\circ} \mathrm{C}(10 \mathrm{~min})$ and then subjected to PRA. DNA fragment of 439 bp was initially amplified by PCR, with the primers Tb 11 (5'ACCAACGATGGTGTGTCCAT) and Tb 12 (5'CTTGTCGAACGCATACCCT), and the amplicon was cleft by restriction enzymes BstEII and HaeIII and separated into fragments by electrophoresis in $4 \%$ agarose gel, which was subsequently developed with ethidium bromide, illuminated with UV light and photographed. Images were captured, stored and analyzed with the help of a gel documentation system. The PRA band patterns were analyzed by comparison with data in the PRASITE data bank: http://app.chuv.ch/prasite/index.html.

\section{RESULTS}

Results of analysis of samples of water and samples from the water distribution system are summarized in Table 1. A total of 110 water samples 


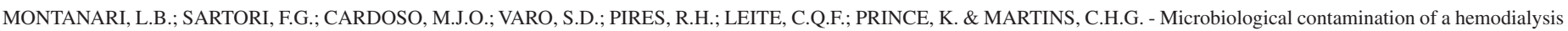
center water distribution system. Rev. Inst. Med. trop. S. Paulo, 51(1): 37-43, 2009.

Table 1

Microorganisms isolated from the water distribution system of a hemodialysis center from November 2004 to July 2006

\begin{tabular}{|c|c|c|c|c|c|c|}
\hline $\begin{array}{l}\text { No. of the } \\
\text { sample }\end{array}$ & Date of isolate & Public water supply & $\begin{array}{c}\text { After reverse } \\
\text { osmosis }\end{array}$ & Room (A) & Room (B) & Room (C) \\
\hline 1 & $11 / 26 / 2004$ & B. subtilis & $\begin{array}{l}\text { P. fluorescens, } \\
\text { B. megaterium }\end{array}$ & $\begin{array}{l}\text { B. megaterium, } \\
\text { A. baumani }\end{array}$ & P. fluorescens & - \\
\hline 2 & $12 / 12 / 2004$ & - & $\begin{array}{l}\text { B. licheniformis, } \\
\text { P. fluorescens, } \\
\text { S. epidermidis }\end{array}$ & B. cereus & S. warneri & $\begin{array}{l}\text { B. cereus, } S \text {. } \\
\text { epidermidis }\end{array}$ \\
\hline 3 & $01 / 12 / 2005$ & - & $\begin{array}{l}\text { P. fluorescens, } \\
\text { B. cereus }\end{array}$ & $\begin{array}{l}\text { B. subtilis, } \\
\text { P. fluorescens, } \\
\text { S. epidermidis }\end{array}$ & P. fluorescens & $\begin{array}{l}\text { P. fluorescens, } \\
\text { B. cereus, } \\
\text { S. marcescens }\end{array}$ \\
\hline 4 & $02 / 12 / 2005$ & B. subtilis & - & - & B. subtilis & - \\
\hline 5 & $03 / 12 / 2005$ & B. subtilis & P. fluorescens & $\begin{array}{c}\text { B. cereus, } \\
\text { M. gordonae } 7\end{array}$ & M. kansasii 3 & $\begin{array}{l}\text { P. fluorescens, } \\
\text { B. cereus, } \\
\text { M. gastri } 1\end{array}$ \\
\hline 6 & $04 / 12 / 2005$ & B. sphaericus & $\begin{array}{l}\text { P. fluorescens, } \\
\text { Alcaligenes sp }\end{array}$ & P. fluorescens & P. fluorescens & - \\
\hline 7 & $05 / 03 / 2005$ & B. licheniformis & - & $\begin{array}{c}\text { S. warneri, } \\
\text { M. kansasii } 3\end{array}$ & $\begin{array}{c}\text { B. sphaericus, } B . \\
\text { cereus, } P \text {. fluorescens, } \\
\text { A. baumanii }\end{array}$ & - \\
\hline 8 & $06 / 12 / 2005$ & P. fluorescens & P. fluorescens & - & $\begin{array}{l}\text { M. kansasii 3, } \\
\text { M. gordonae } 3 \text {, } \\
\text { M. lentiflavum } 1\end{array}$ & P. fluorescens \\
\hline 9 & $07 / 12 / 2005$ & B. cereus & P. aeruginosa & $\begin{array}{l}\text { P. aeruginosa, } \\
\text { M. gastri } 1\end{array}$ & $\begin{array}{l}\text { P. aeruginosa, } \\
\text { M. gastri } 1\end{array}$ & Alcaligenes sp. \\
\hline 10 & $07 / 27 / 2005$ & P. stutzeri & $\begin{array}{l}\text { P. aeruginosa, } \\
\text { S. xylosus }\end{array}$ & P. aeruginosa & P. aeruginosa & P. aeruginosa \\
\hline 11 & $08 / 12 / 2005$ & & & P. aeruginosa & P. aeruginosa & P. aeruginosa \\
\hline 12 & $09 / 15 / 2005$ & $\begin{array}{c}\text { B. thuringiensis, } \\
\text { S. maltophilia }\end{array}$ & S. xylosus & P. aeruginosa & $\begin{array}{l}\text { P. aeruginosa, } \\
\text { B. thuringiensis }\end{array}$ & P. stutzeri \\
\hline 13 & $10 / 10 / 2005$ & S. maltophilia & P. aeruginosa & P. aeruginosa & P. aeruginosa & F. odoratum \\
\hline 14 & $11 / 12 / 2005$ & $\begin{array}{l}\text { S. maltophilia, } \\
\text { F. odoratum }\end{array}$ & P. aeruginosa & P. aeruginosa & - & $\begin{array}{c}\text { P. aeruginosa, } \\
\text { F. odoratum }\end{array}$ \\
\hline 15 & $12 / 12 / 2005$ & $\begin{array}{l}\text { S. maltophilia, } \\
\text { B. thuringiensis } \\
\text { P. aeruginosa, } \\
\text { S. hyicus }\end{array}$ & $\begin{array}{l}\text { S. maltophilia, } \\
\text { F. odoratum }\end{array}$ & - & - & S. maltophilia \\
\hline 16 & $01 / 10 / 2006$ & $\begin{array}{l}\text { B. thuringiensis, } \\
\text { F. odoratum, } \\
\text { P. aeruginosa }\end{array}$ & P. aeruginosa & - & - & S. xylosus \\
\hline 17 & $02 / 12 / 2006$ & P. stutzeri & F. odoratum & - & B. cepaceae & F. odoratum \\
\hline 18 & $03 / 14 / 2006$ & P. stutzeri & S. xylosus & F. odoratum & P. aeruginosa & P. stutzeri \\
\hline 19 & $04 / 10 / 2006$ & $\begin{array}{c}\text { P. stutzeri, } \\
\text { B. thuringiensis }\end{array}$ & - & - & - & P. stutzeri \\
\hline 20 & $05 / 12 / 2006$ & P. stutzeri & - & P. putida & P. putida & P. putida \\
\hline 21 & $06 / 15 / 2006$ & $\begin{array}{l}\text { B. thuringiensis, } \\
\text { N. brevicatena }\end{array}$ & N. brevicatena & $\begin{array}{c}\text { P. putida, } \\
\text { P. macerans }\end{array}$ & P. aeruginosa & P. alvei \\
\hline 22 & $07 / 17 / 2006$ & $\begin{array}{l}\text { P. aeruginosa, } \\
\text { N. brevicatena }\end{array}$ & $\begin{array}{l}\text { P. aeruginosa, } \\
\text { N. brevicatena }\end{array}$ & P. aeruginosa & P. aeruginosa & $\begin{array}{l}\text { P. aeruginosa, } \\
\text { B. thuringiensis }\end{array}$ \\
\hline
\end{tabular}


MONTANARI, L.B.; SARTORI, F.G.; CARDOSO, M.J.O.; VARO, S.D.; PIRES, R.H.; LEITE, C.Q.F.; PRINCE, K. \& MARTINS, C.H.G. - Microbiological contamination of a hemodialysis center water distribution system. Rev. Inst. Med. trop. S. Paulo, 51(1): 37-43, 2009.

collected were analyzed in 22 collections from each of five points in the water distribution system of the hemodialysis center yielded a total of 128 bacterial isolates. The distribution of different species found at the different sampling point is presented in Table 1 . One or more species of bacteria were found in $80 \%$ (88/110) of the samples, while the samples without any bacterial growth were seen mainly in the $4^{\text {th }}$ and $19^{\text {th }}$ collections $(3 / 110=$ $2.72 \%)$ and in dialysis room A (collection point III) $(6 / 110=5.4 \%)$.

The fraction of water system isolates shown to be mycobacteria was $7.1 \%$ (9/128), 92.9\% (119/128) being identified as other species. The mycobacteria were not evenly distributed, being detected only in the $5^{\text {th }}, 7^{\text {th }}, 8^{\text {th }}$ and $9^{\text {th }}$ collections. The most prevalent bacterial species recovered were Pseudomonas aeruginosa (28), P. fluorescens (16), Bacillus cereus, P. stutzeri and Flavobacterium odoratum (8). PRA identification of isolates obtained from positive water samples showed that the predominant species of Mycobacterium were M. gastri 1 ( $3=$ $33.3 \%)$ and $M$. kansasii $3(3=33.3 \%)$. The mycobacteria were recovered mostly $(55 \%)$ at point IV (dialysis room B) and consisted entirely of four species: M. kansasii 3 (2/25), Mycobacterium gordonae 3 (1/25), Mycobacterium lentiflavum 1 and M. gastri 1 (1/25). Note that all mycobacteria were found in the dialysis rooms or reuse system, while the other acid-fast genus, Nocardia, was only found earlier in the system points I and II (Tables 1 and 2).

Table 2

Microorganisms isolated from water in the dialyser reuse system at a hemodialysis center in two samples from November 2004 to July 2006

\begin{tabular}{lc}
\hline Isolated bacteria & Number of isolates \\
\hline Staphylococcus epidermidis & 1 \\
Mycobacterium gordonae 2 & 1 \\
Mycobacterium gordonae 3 & 1 \\
\hline TOTAL & 3 \\
\hline
\end{tabular}

In the samples taken in the public water supply, 29 isolates were recovered, P. stutzeri and Bacillus thuringiensis prevailing with five isolates each. At the second collecting point, downstream of the reverse osmosis filter, P. aeruginosa and P. fluorescens was prevailing, with six isolates each $(12 / 26=46.2 \%$ - Table 1$)$. In the dialysis rooms A (III), $\mathrm{B}$ (IV) and C (V), 73 bacterial isolates (Table 1) were recovered and identified as: $P$. aeruginosa $(19 / 73=26 \%)$, P. fluorescens $(9 / 73=12.3 \%)$, B. cereus $(6 / 73=8.2 \%)$, Pseudomonas putida $(4 / 73=5.5 \%)$, F. odoratum $(4 / 73=5.5 \%)$ and $M$. gastri $1(3 / 73=4.1 \%)$.

The 36 water samples taken from the outlet cannulae of the kidney machines (dialysate) yielded 43 bacterial isolates (Table 3), while five of the samples (13.9\%) showed no bacterial growth. Among the bacterial isolates, $P$. aeruginosa $(13=30.2 \%)$ was the most frequent species, while Staphylococcus epidermidis $(8=18.6 \%)$ was the most evenly distributed in the dialysis water of the machines in the three rooms A, B and C. Other species (Table 3) found here were P. stutzeri $(8=18.6 \%)$, Escherichia coli $(7=16.3 \%)$, Klebsiella pneumoniae and Stenotrophomonas maltophilia $(2=4.6 \%)$ and B. cereus, $P$. putida and F. odoratum $(1=2.3 \%)$.

Only three isolates were recovered from the reuse system (Table 2) sampling site: S. epidermidis (1), M. gordonae 2 (1) and M. gordonae
Table 3

Microorganisms isolated from water in kidney machine at a hemodialysis center from November 2004 to July 2006

\begin{tabular}{|c|c|c|}
\hline Machine & Date of isolate & Isolated bacteria \\
\hline 1 & $11 / 26 / 2004$ & E. coli \\
\hline 2 & $12 / 12 / 2004$ & P. aeruginosa \\
\hline 3 & $12 / 12 / 2004$ & - \\
\hline 4 & $01 / 12 / 2005$ & P. aeruginosa, S. epidermidis \\
\hline 5 & $01 / 12 / 2005$ & P. aeruginosa \\
\hline 6 & $02 / 12 / 2005$ & P. aeruginosa \\
\hline 7 & $02 / 12 / 2005$ & E. coli, S. epidermidis \\
\hline 8 & 03/12/2005 & E. coli \\
\hline 9 & $04 / 12 / 2005$ & P. aeruginosa \\
\hline 10 & 05/03/2005 & P. stutzeri, E. coli \\
\hline 11 & $06 / 12 / 2005$ & P. aeruginosa, $P$. stutzeri \\
\hline 12 & $06 / 12 / 2005$ & E. coli \\
\hline 13 & $07 / 12 / 2005$ & S. epidermidis \\
\hline 14 & 07/27/2005 & B. cereus \\
\hline 15 & 08/12/2005 & P. stutzeri \\
\hline 16 & 08/12/2005 & S. maltophilia \\
\hline 17 & $09 / 15 / 2005$ & - \\
\hline 18 & $09 / 15 / 2005$ & S. epidermidis \\
\hline 19 & $10 / 10 / 2005$ & S. epidermidis, P. stutzeri \\
\hline 20 & $10 / 10 / 2005$ & P. stutzeri \\
\hline 21 & $11 / 12 / 2005$ & P. stutzeri \\
\hline 22 & $11 / 12 / 2005$ & P. aeruginosa \\
\hline 23 & $12 / 12 / 2005$ & P. aeruginosa \\
\hline 24 & $12 / 12 / 2005$ & P. stutzeri \\
\hline 25 & 01/10/2006 & P. aeruginosa, K. pneumoniae \\
\hline 26 & $01 / 10 / 2006$ & - \\
\hline 27 & $02 / 12 / 2006$ & P. aeruginosa \\
\hline 28 & 03/14/2006 & S. epidermidis, K. pneumoniae \\
\hline 29 & 03/14/2006 & S. epidermidis, P. stutzeri \\
\hline 30 & 04/10/2006 & E. coli \\
\hline 31 & 05/12/2006 & - \\
\hline 32 & 05/12/2006 & P. aeruginosa, S. epidermidis, E. coli \\
\hline 33 & 06/15/2006 & - \\
\hline 34 & 07/17/2006 & P. aeruginosa \\
\hline 35 & 07/17/2006 & P. putida, S. maltophilia \\
\hline 36 & 07/17/2006 & F. odoratum, P. aeruginosa \\
\hline
\end{tabular}

3 (1). Finally, nine isolates were recovered from the 13 samples taken from the water storage tank (Table 4), the most frequent species being $P$. aeruginosa $(3=33.3 \%)$ and Burkholderia cepacia $(2=22.2 \%)$.

The numbers of bacteria found in the water, both in the distribution system and in the machine cannulae, averaged 2.5 and $3.0 \mathrm{CFU} / \mathrm{mL}$ respectively, considered a rather low density. Moreover none of the 10 samples of sterilizing solution produced any bacterial growth. 


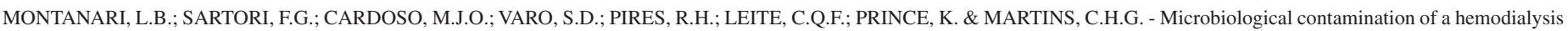
center water distribution system. Rev. Inst. Med. trop. S. Paulo, 51(1): 37-43, 2009.

Table 4

Microorganisms isolated from water in the storage tank at a hemodialysis center in thirteen samples from November 2004 to July 2006

\begin{tabular}{lc}
\hline Isolated bacteria & Number of isolates \\
\hline Pseudomonas aeruginosa & 3 \\
Bacillus thuringiensis & 1 \\
Staphylococcus hyicus & 1 \\
Pseudomonas putida & 1 \\
Burkholderia cepacia & 2 \\
Agrobacterium tumefaciens & 1 \\
\hline TOTAL & 9 \\
\hline
\end{tabular}

\section{DISCUSSION}

Over the last two decades there has been considerable progress in our understanding of microbial pathogenesis in hemodialysis patients, and the current emphasis is on patient immunity, bacterial virulence and the dialysis process itself ${ }^{18}$. It is now well established that dialysis fluid quality depends on a complex chain of devices and procedures, and the quality control procedure implemented. The correct working of the preparatory process (pre-treatment) and the final phase of depuration (reverse osmosis) of the system need a periodic preventive maintenance and the regular substitution of worn or exhausted components by a competent and trained staff. Routine disinfection of the membranes of reverse osmosis and the water distribution system, including dialysis machine connections, should be submitted to disinfections at least monthly. For this purpose it is possible to use chemical and physical agents according to manufacturer recommendations. In dialysis center studied, the system disinfection is carried out with peracetic acid and at a minimum of 60 minutes of disinfection time, every night.

Every week, hemodialysis patients are exposed to approximately 400 and 600 liters of water used for the production of dialysis fluid ${ }^{31}$. High concentrations of bacteria can pose risks of bacteremia or endotoxemia to hemodialysis patients ${ }^{17}$ because of possible passage of bacterial endotoxin across the membrane or because transmembrane stimulation of macrophages and subsequent cytokine production by endotoxin or bacteria ${ }^{4}$.

A variety of microorganisms can multiply rapidly in various fluids found in the water-processing units at a hemodialysis center, including the water produced by distillation, deionization, reverse osmosis and softening, is normally assumed to be nutrient-free ${ }^{15}$. If the level of bacterial contamination then surpasses the currently accepted limits, the result can be septicemia or endotoxemia by Gram-negative bacteria $^{6,8,18,33}$.

The low viable counts (2.5 and 3.0 CFU/mL) detected in this study indicate that the microbiological quality of the water analyzed was well below the limits recommended by the $\mathrm{AAMI}^{2}$ and the Brazilian Health Ministry ${ }^{24}$. In contrast to the earlier study by PISANI et al. ${ }^{28}$, in a hemodialysis unit in the city of Campinas (SP, Brazil), reported that a viable count of $300 \mathrm{CFU} / \mathrm{mL}$, exceeding the Health Ministry limit of 200 $\mathrm{CFU} / \mathrm{mL}$, established subsequently in 2004. Regarding mycobacteria, there are no regulatory standards on their detection and quantitation in hemodialysis water.

Currently in relation to microbiological limits and the techniques of cultivation, in addition to the international standard of AAMI (RD62:2006) ${ }^{2}$, there is an equivalent International Standard (ISO 13959) currently under revision, proposing the reduction of both bacterial levels $(<100 \mathrm{CFU} / \mathrm{mL})$ and endodotoxin levels in this new standard which is due for publication in 2009. Within this recommendations are made concerning culture techniques namely, for bacteria: Tryptone Glucose Extract Agar (TGEA) and Reasoner's Agar (R 2A) at $17-23^{\circ} \mathrm{C}$ for seven days. A recommended practice providing guidelines for the use, care, and/or processing of a medical device or system is necessarily a static document applied to a dynamic technology.

The results obtained in this study showed that the bacteria most frequently associated with the water used in the dialysis fluid and in the kidney machine were Pseudomonas sp, S. epidermidis, B. cereus, E. coli and $S$. maltophilia, in general agreement with results obtained by ARVANITIDOU et al. ${ }^{6}$, who reported the predominance of $P$. aeruginosa, S. maltophilia and E. coli in the isolates.

Enterobacteria were recovered in $5.5 \%(10 / 183)$ of the isolates. This finding was supported by increasing reports of Gram-negative rods causing frequent infections in hemodialysis and is the main cause of morbidity among patients undergoing this treatment ${ }^{19,33}$.

The genus Pseudomonas was found in 44\% (80/183) of the bacteria isolated, both in the water distribution system and the dialysate. This result gives cause for concern, in view of the well-known resistance to biocides and antibiotics shown by bacteria of this genus, which is often cited as the causative agent in reports of septicemia and endotoxemia ${ }^{3,18,27}$.

Some studies have suggested that drinking water and water used to prepare dialysate ${ }^{3,7}$ have already pointed to genus Pseudomonas as the most commonly isolated. OIE et al. ${ }^{27}$ showed that dialysis solutions are most frequently contaminated with heterotrophic bacteria, $P$. aeruginosa and fungi. The present investigation indicates that $P$. aeruginosa represented $24.0 \%$ of the bacteria isolated, a result very similar to the $22.7 \%$ found by ARVANITIDOU et al. ${ }^{6}$. On the other hand, very different isolation frequencies, $1.6 \%$ and $56 \%$ respectively, have been described for $P$. aeruginosa by ZUNINO et al..$^{40}$ and PISANI et al..$^{28}$. P. aeruginosa is being related more and more to virulence factors, multiple resistance to a large number of antimicrobial agents, ready acquisition of new resistance factors and its capacity to survive in water for long periods, even without nutrients. For these reasons, this species is being studied closely with a view to establishing new means to eliminate it from dialysis water ${ }^{3}$.

Other species of Pseudomonas were identified in the samples: $P$. fluorescens, $P$. stutzeri, $P$. putida and $P$. alcaligenes. Immediately following water treatment (point II), the most prevalent of these was $P$. fluorescens, equaling P. aeruginosa at $46.1 \%(6 / 13)$ of the isolates.

Microorganisms recovered in public supply included $P$. stutzeri (5/29), Bacillus thuringiensis (5/29), Stenotrophomonas maltophilia (4/29), P. aeruginosa, Bacillus subtilis (3/29), Flavobacterium odoratum, Nocardia brevicatena complex (2/29), Bacillus sphaericus (1/29), Bacillus licheniformis (1/29), P. fluorescens (1/29), B. cereus 
MONTANARI, L.B.; SARTORI, F.G.; CARDOSO, M.J.O.; VARO, S.D.; PIRES, R.H.; LEITE, C.Q.F.; PRINCE, K. \& MARTINS, C.H.G. - Microbiological contamination of a hemodialysis center water distribution system. Rev. Inst. Med. trop. S. Paulo, 51(1): 37-43, 2009.

$(1 / 29)$, and were also present in the later, treated stages (points II to $\mathrm{V})$, suggesting that the tubing, especially on the machines, should be a site of biofilm growth. Supporting this suggestion, P. aeruginosa, $S$. epidermidis and B. cereus were isolated both from the post-treatment water system (II, III, IV and V) and from the dialysis solutions (hemodialysis machine water). The formation of biofilms, which promote the persistence of bacteria at various points in the system and protect them form disinfection, increases the risk of contamination and raises the levels of endotoxins in the water ${ }^{25}$. OIE et al. ${ }^{27}$ have suggested that dialysis solution is especially prone to be contaminated in this way and they recommended placing an ultra-filtration membrane at the entrance of the dialyser, to stop any contaminant in the dialysis solution from gaining entrance.

The incidence of E. coli in this study was $16.3 \%$ (7/43) of the 43 bacteria identified in the dialysate. This result agrees with data reported by ARVANITIDOU et al. ${ }^{6}$ that also demonstrated a prevalence of $E$. coli among Gram-negative bacterial isolates from the dialysate (12.8\%). Other species found in the water from the machines, in order of decreasing frequency, were: 13 P. aeruginosa, eight $S$. epidermidis and $P$. stutzeri, two $S$. maltophilia and K. pneumoniae and one B. cereus, P. putida and $F$. odoratum. LIMA et al..$^{23}$ reported the isolation of $S$. maltophilia and B. cepacia in water samples taken directly from points before and after water treatment and from the kidney machines.

The water distributed to the dialysis and reuse rooms yielded 11 isolates of non-tuberculous mycobacteria (NTM): 4 Mycobacterium gordonae, 3 M. kansasii 3, 3 M. gastri 1 and 1 M. lentiflavum 1 . In a drinking-water treatment system, LE DANTEC et al. ${ }^{21}$ also reported the predominance of $M$. gordonae in post-filtration water. It should be noted that in our study the potentially pathogenic M. kansasii 3 was isolated three times; this species has been responsible for infections in immunodeficient patients ${ }^{12}$. On the other hand, although M. lentiflavum was isolated just once, it has often been found during outbreaks of hospital infection, contaminating equipment and medicines ${ }^{37,39}$. Bacteria of the genes Mycobacterium have been isolated from a variety of natural aquatic habitats and are capable of growing in treated water and dialysis fluids, colonizing surfaces inside tanks, kidney machines and components of the water treatment system such as deionizing resins and reverse-osmosis membranes ${ }^{11,32}$. Due to their readiness to form biofilms, mycobacteria can colonize many parts of the dialysis water system ${ }^{16}$, being harder to eradicate by virtue of their tolerance to disinfectant chemicals, like chlorine and ozone, is several orders of magnitude higher than that of Escherichia coli ${ }^{17,28}$.

Uremic patients are at higher risk from biofilms as not only traditional causes, such as indwelling catheters, but also hemodialysis apparatuses contribute to bacterial exposure. Chemical or physical disinfections have been demonstrated partially active on sessile microorganisms and biofilm avoidance remains the goal to assure an adequate quality of dialytic treatment ${ }^{10}$.

\section{CONCLUSION}

In this study, the detection of a variety of bacteria, including mycobacteria, in hemodialysis water indicates the necessity of regular appropriate monitoring by the local health authority, to ensure the best possible control over the water treatment system. Although the total bacterial count was well within the standards required by existing legislation, as laid down by the Brazilian Health Ministry, there are no regulations regarding mycobacteria. The fact that NTM were isolated demonstrates that the dialysis water system can constitute a reservoir and a means of transmitting rarely pathogenic and potentially pathogenic mycobacteria among a population whose immunity is debilitated, such as long-term kidney disease patients.

\section{RESUMO}

\section{Contaminação microbiológica no sistema de distribuição de água de um centro de hemodiálise}

O monitoramento microbiológico da água utilizada no procedimento de hemodiálise é de extrema importância, principalmente devido à imunodebilidade dos pacientes com insuficiência renal crônica. Nosso objetivo foi verificar qualitativa e quantitativamente a presença de bactérias na água de um centro de hemodiálise do interior do Estado de São Paulo. Foram realizadas 22 coletas de cada um dos cinco pontos do sistema de distribuição; 36 amostras de 19 máquinas de hemodiálise, prontas para utilização; quatro amostras do sistema de reuso e 13 amostras do sistema de armazenamento de água, empregando-se a técnica da membrana filtrante com poros de $0,22 \mu \mathrm{m}$ para bactérias e de $0,45 \mu \mathrm{m}$ para micobactérias. A identificação foi realizada através de métodos microbiológicos convencionais e de biologia molecular. Isolados bacterianos foram obtidos de sistema de distribuição (128), águas das máquinas (43) e sistema de reuso (3). Entre os isolados 32 foram de bacilos Gram-positivos, 120 bacilos Gram-negativos, 20 Cocos Gram-positivos e 11 micobactérias. Neste estudo, sugerimos que suprimentos de água para o Centro de Hemodiálise devam ser monitorados, adotando-se medidas profiláticas eficazes que minimizem a exposição destes pacientes imunodeficientes a fontes aquáticas ambientais contaminadas.

\section{REFERENCES}

1. AMERICAN PUBLIC HEALTH ASSOCIATION - Standard methods for the examination of water and wastewater. Washington, APHA, 2005. p. 9-1 - 9-41.

2. ASSOCIATION FOR THE ADVANCEMENT OF MEDICAL INSTRUMENTATION (AAMI) - Water treatment equipment for hemodialysis applications. ANSI/AAMI RD62:2006.

3. ARDUINO, M.J.; BLAND, L.A.; AGUERO, S.M. et al. - Comparison of microbiologic assay methods for hemodialysis fluids. J. clin. Microbiol., 29: 592-594, 1991.

4. ARDUINO, M.J. - Monitoring and prevention of disease transmission in dialyser reuse facilities. Current concepts in hemodialyzer reprocessing. Association for the Advancement of Medical Instrumentation(AAMI). Dialysis Monograph Series, 23-32, 1998

5. ARVANITIDOU, M.; SPAIA, S.; KATSINAS, C. et al. - Microbiological quality of water and dialysate in all haemodialysis centres of Greece. Nephrol. Dial. Transplant., 13: 949-954, 1998.

6. ARVANITIDOU, M.; VAYONA, A.; SPANAKIS, N. \& TSAKRIS, A. - Occurrence and antimicrobial resistance of Gram-negative bacteria isolated in haemodialysis water and dialysate of renal units: results of a Greek multicentre study. J. appl. Microbiol., 95: $180-185,2003$

7. BAMBAUER, R.; SCHAUER, M.; JUNG, W.K.; DAUM, V. \& VIENKEN, J. Contamination of dialysis water and dialysate. A survey of 30 centers. ASAIO J., 40: 1012-1016, 1994. 

center water distribution system. Rev. Inst. Med. trop. S. Paulo, 51(1): 37-43, 2009.

8. BLOCK, C.; BACKENROTH, R.; GERSHON, E. et al. - Outbreak of bloodstream infection associated with dialysis machine waste ports in a hemodialysis facility. Europ. J. clin. Microbiol. infect. Dis., 18: 723-725, 1999.

9. CAPELLI, G.; RICCARDI, M.; PERRONE, S. \& BONDI, M. - Water treatment and monitor desinfection. Hemodial. Int., 10 (suppl. 1): S13-S18, 2006.

10. CAPPELLI, G.; RICARDI, M.; RAVERA, M. et al. - Biofilm on artificial surfaces. Contrib. Nephrol., 154: 61-71, 2007.

11. CARSON, L.A.; CUSICK, L.B.; BLAND, L.A. \& FAVERO, M.S. - Efficacy of chemical dosing methods for isolating nontuberculous mycobacteria from water supplies of dialysis centers. Appl. environ. Microbiol., 54: 1756-1760, 1988.

12. DELCLAUX, C.; LADERICH, J.; ADOTTI, F. \& KLEINKNECHT, D. - Fatal disseminated Mycobacterium kansasii infection in a hemodialysis patient. Nephron, 64: 155-156, 1993

13. EUROPEAN BEST PRACTICE GUIDELINES FOR HAEMODIALYSIS (part 1). Section IV - Dialysis fluid purity. Nephrol. Dial. Transplant, 17 (suppl. 7): 45-62, 2002

14. FALKINHAM III, J.O.; NORTON, C.D. \& LE CHEVALLIER, M.W. - Factors influencing numbers of Mycobacterium avium, Mycobacterium intracellulare and other mycobacteria in drinking water distribution systems. Appl. environ. Microbiol., 67: $1225-1231,2001$

15. FAVERO, M.S.; PETERSEN, N.J.; CARSON, L.A.; BOND, W.W. \& HINDMAN S.H. - Gram-negative bacteria in hemodialysis systems. Hlth Lab. Sci., 12: 321-334, 1975

16. GROOTE, M.A. \& HUITT, G. - Infections due to rapidly growing mycobacteria Clin. infect. Dis., 42: 1756-1763, 2006.

17. HOENICH, A.N. \& RONCO, C. - Hemodialysis fluid: composition and clinical importance. Blood Purif., 25: 62-68, 2007.

18. JABER, B.L. - Bacterial infections in hemodialysis patients: pathogenesis and prevention. Kidney Int., 67: 2508-2519, 2005.

19. JOCHIMSEN, E.M.; FRENETTE, C.; DELORME, M. et al. - A cluster of bloodstream infection and pyrogenic reaction among hemodialysis patients traced to dialysis machine waste-handling option units. Amer. J. Nephrol., 18: 485-489, 1998.

20. LEITE, C.Q.F.; DAVID, H. \& LÉVY FRÉBAULT, V. - Prevalência e distribuição de micobactérias nas águas de algumas regiões do Estado de São Paulo - Brasil. Rev. Microbiol., 20: 432-441, 1989.

21. LE DANTEC, C.; DUGUET, J.P.; MONTIEL, A. et al. - Occurrence of Mycobacteria in water treatment lines and in water distribution systems. Appl. environ. Microbiol., 68: 5318-5325, 2002

22. LEDEBO, I. - Ultrapure dialysis fluid---how pure is it and do we need it? Nephrol. dial. Transplant., 22: 20-23, 2007.

23. LIMA, J.R.O.; MARQUES, S.G.; GONÇALVES, A.G. et al. - Microbiological analyses of water from hemodialysis services in São Luís, Maranhão, Brazil. Braz. J. Microbiol., 36: 103-108, 2005

24. MINISTÉRIO DA SAÚDE. Brasil - Portaria 154/GM de 15.06.2004. D. O. Seção I 08.02.2000. Regulamento técnico para o funcionamento dos serviços de diálise. 8 . Qualidade da água. Brasília, Ministério da Saúde, 2004.
25. MORIN, P. - Identification of the bacteriological contamination of a water treatment line used for hemodialysis and its disinfection. J. Hosp. Infect., 45: 218-224, 2000.

26. MURRAY, P.R.; BARON, E.J.; PFALLER, M.A.; TENOVER, F.C. \& YOLKEN, R.H. - Manual of clinical Microbiology. 7. ed. Washington, American Society for Microbiology, 1999.

27. OIE, S.; KAMIYA, A.; YONEDA, I. et al. - Microbial contamination of dialysate and its prevention in haemodialysis units. J. Hosp. Infect., 54: 115-119, 2003.

28. PISANI, B.; SIMÕES, M.; PRANDI, M.A.G. et al. - Surto de bacteremia por Pseudomonas aeruginosa na unidade de hemodiálise de um hospital de Campinas, São Paulo, Brasil. Rev. Inst. Adolfo Lutz, 59: 51-56, 2000

29. PIRES-GONÇALVES, R.H.; SARTORI, F.G.; MONTANARI, L.B. et al. Occurrence of fungi in water used at a haemodialysis centre. Lett. appl. Microbiol., 46: $542-547,2008$.

30. PIZZARELli, F.; CERRAI, T.; BIAGINI, M.; MALAGUTI, M. \& BARGAGNA R. - Dialysis water treatment systems and monitoring in Italy: results of a national survey. J. Nephrol., 17: 565-569, 2004

31. PONTORIERO, G.; POZZONI, P.; ANDRULLI, S. \& LOCATELLI, F. - The quality of dialysis water. Nephrol. Dial. Transplant., 18 (suppl.7): 21-25, 2003.

32. RIDGWAY, H.F.; RIGBY, M.G. \& ARGO, D.G. - Adhesion of a Mycobacterium sp to cellulose diacetate membranes used in reverse osmosis. Appl. environ. Microbiol. 47: 61-67, 1984

33. ROTH, V.R. \& JARVIS, W.R. - Outbreaks of infection and/or pyrogenic reaction in dialysis patients. Semin. Dial., 13: 92-96, 2000.

34. SILVA, A.M.; MARTINS, C.T.B.; FERRABOLI, R.; JORGETTI, V. \& ROMÄO JUNIOR, J.E. - Revisão/Atualização em diálise: água para hemodiálise. J. bras. Nefrol., 2: 180-188, 1996

35. TAYLOR, R.H.; FALKINHAM III, O.J.; NORTON, C.D. \& LECHEVALLIER, M.W - Chlorine, chloramine, chlorine dioxide, and ozone susceptibility of Mycobacterium avium. Appl. environ. Microbiol., 66: 1702-1705, 2000.

36. TELENTI, A.; MARCHESI, F.; BALZ, M. et al. - Rapid identification of mycobacteria to the species level by polymerase chain reaction and restriction enzyme analysis. $\mathbf{J}$. clin. Microbiol., 31: 175-178, 1993.

37. TORTOLI, E.; MATTEI, R.; RUSSO, C. \& SCARPARO, C. - Mycobacterium lentiflavum, an emerging pathogen? J. Infect., 52: 185-187, 2006.

38. VANHOLDER, R.; VANHAECKE, E. \& RINGOIR, S. - Waterborne Pseudomonas septicemia. ASAIO Trans., 36: M215-M216, 1990

39. YAKRUS, M.A.; HERNANDEZ, S.M.; FLOYD, M.M. et al. - Comparison of methods for identification of Mycobacterium abscessus and M. chelonae isolates. J. clin. Microbiol., 39: 4103-4110, 2001.

40. ZUNINO, P.; BELTRÁN, L.; ZUNINO, L. et al. - Microbiological quality of hemodialysis water in a three-year multicenter study in Uruguay. J. Nephrol., 15: 374-379, 2002.

Received: 25 June 2008

Accepted: 11 December 2008 